\title{
The Impact of COVID-19 'Hard' Lockdown Disaster Management Regulations on Small- scale Farmers: The Case of Central and Southern KZN Small-scale Farmers Employing Climate Resilient Agriculture Production
}

\section{Desiree P. Manicom \\ ORCiD ID: https://orcid.org/0000-0001-8458-2455}

\section{Erna Kruger \\ ORCiD ID: https://orcid.org/0000-0003-1250-5922}

\begin{abstract}
South Africa remains a highly unequal and divided society and the disaster measures of lockdown, designed to contain the spread of COVID-19, are being implemented within a context where people have vastly different abilities to access crucial food resources and health facilities. Small-scale farmers play an important role in providing food to their local communities and families. The fresh produce they provide is crucial to their own and their communities' nutritional health, as well as to the sustainability of their livelihoods. The COVID-19 pandemic has revealed the vulnerability of South Africa's food system through the widespread hunger and food shortages, which have been reported as some of the dire consequences of the lockdown. This article discusses the experiences of small-scale farmers under the COVID-19 lockdown restrictions, in terms of their resilience and food security. Data for the research were drawn from the findings of a small qualitative structured survey that was conducted with small-scale farmers in a climate resilient agriculture (CRA) programme, run by Mahlathini Development Foundation (MDF). The results of the study show that the COVID-19 lockdown regula-
\end{abstract}


tions specifically relating to restrictions on the movement of persons and goods, and the prohibition of public transport impacted negatively on smallscale farmers' sense of resilience, livelihoods and agricultural activities. The enforcement of social distancing restrictions by the police impacted negatively on their ability to act as a community and their ability to support the vulnerable. The study concludes that small-scale farmers' agricultural production plays an important role in ensuring local food provision in villages and in maintaining their own food security. There were serious limitations in the drafting and implementation of lockdown regulations which did not consider the specific conditions of the rural poor. These limitations relate to policymakers' drafting of and implementing disaster management regulations in isolation, with 'Command and control' measures most frequently being used instead of consultation with interest groups and putting into place timeous, adequate and appropriate mitigation measures.

Keywords: COVID-19, lockdown regulations, small-scale farmers, climate resilient agriculture, conservation agriculture, food insecurity

\section{Introduction}

The COVID-19 pandemic has revealed the vulnerability of South Africa's food system and that South Africa remains a highly unequal and divided society. COVID-19 lockdown regulations and relief measures were implemented by the South African government to mitigate the spread of the virus and the effects of lockdown measures. However, this has impacted unevenly on various groups within South African society. Some groups and some sectors are socioeconomically more vulnerable than others. The transmission and infection rates of the pandemic, as well as the impact of lockdown regulations will most likely imprint along the divisions and inequalities that are prevalent in South Africa. One of the inequalities that divide people is food security - an issue that predates COVID.

According to StatsSA (2017) almost $20 \%$ of South African households had inadequate or severely inadequate access to food in 2017. Severely inadequate access to food was mostly found in households with more than eight members. The study found that about 1,7 million households experienced hunger in 2017 (ibid). About $85 \%$ of households in rural, communal tenure communities in South Africa fall within the poorest category of South Africans 
(StatsSA 2016). More than half a million (611 000) households, with children aged five years or younger, experienced hunger in 2017. This constitutes $13,1 \%$ of households with children aged five years or younger. Northern Cape and KwaZulu-Natal had the highest proportion of such households.

Small-scale farmers play an important role in providing food to their local communities and families. The fresh produce they provide is crucial to their own and their communities' nutritional health as well as to the sustainability of their livelihoods. Small-scale farmers use a diversified farming system, namely, $50-500 \mathrm{~m}^{2}$ intensive vegetable and fruit production, 0,1-2ha field cropping, and livestock management (usually between 10-50 chickens, 5-10 goats and 3-20 cattle) (Smith, Kruger, Knot \& Blignaut 2017). It is argued that small-scale farming does not lend itself innately to the commercial scaling that modern economies require, but does lend itself strongly to local food security potential and local value chains that can take advantage of small amounts of produce gathered from many different producers (Kruger, Smith, Ngcobo, Dlamini \& Mathebula 2017).

According to the $\mathrm{C} 19$ submission, small-scale farmers include:

- Farmers and household producers (mainly women) who produce for their own subsistence.

- Farmers and household producers (mainly women) who sell small surpluses into informal markets (pension pay points or at the gate) often on a cash basis.

- Small-scale farmers (mainly women) who manage mixed farming systems including crops and livestock, farm in low input and often organic or agroecological systems, who do not purchase chemicals and fertilisers from corporate retailers but use local suppliers of manure, seedlings, seeds, effective micro-organisms, biopesticides and veterinary requirements.

- Small-scale farmers who do not farm full-time but use small injections of cash from farming as a critically important component to sustain mixed livelihoods that are often heavily dependent on grants.

- Farmers of non-food products such as rooibos tea, essential oils or herbs such as buchu

(CR19 National Food Group 2020). 
The term smallholder, thus encompasses a wide range of situation and productive capacity.

\section{COVID-19 Disaster Management Regulations}

The Disaster Management Act, 2002: Amendment of Regulations issued in Terms of Section 27 (2) was promulgated on 25 March 2020. The Amendments to the Act were specifically designed to contain the spread of the COVID-19 virus. The lockdown regulations were designed as a series of five alert levels in a risk-adjusted approach with varying degrees of restrictions on the movement of persons and the transportation and sale of goods and services (RSA 2020). All levels of lockdown are meant to restrict people to their homes and movement allowed only for the purchase of food, for health reasons and to go to work. Strict health protocols at work and social distancing rules are applicable to all lockdown levels. Levels 5 and 4 lockdowns were a hard lockdown; Level 5 was in effect between 26 March 2020 and 31April 2020 and Level 4 between 1 and 31 May 2020. Level 3 lockdown extended from 1 June to 17 August 2020, while Level 3 started on 18 August 2020. A categorisation of the permitted sale and purchase of essential goods and services during lockdown was published as annexures to the amended Disaster Management legislation (RSA 2020).

The research on small-scale farmers focused on the periods of lockdown levels 5 and 4. Under Level 5, commuter transport services were also prohibited except for those providing services for purposes of rendering or obtaining essential services, providing transport for citizens seeking medical attention and or attending funerals or to receive grant payments (RSA 2020). Capacity of public transport vehicles was restricted to 50\%. Further, persons had to comply with being tested for COVID-19 and to being admitted to a health establishment or quarantine or isolation site. Under Level 5, agricultural inputs were not deemed an essential good and informal trading was not permitted. Under Level 4, agriculture was permitted, and this included preparation, cultivation, harvesting and storage essential to preventing the wastage of primary agricultural, fishing and forestry goods. The sale of food products by informal traders was permitted. A curfew was introduced which restricted the movement of people between $8 \mathrm{pm}$ and 5am except for essential service workers. 
This study explored the impact of levels 5 and 4 lockdown regulations on the lives of groups of small-scale farmers living in a region of Kwazulu Natal who were participating in a climate resilient agricultural production programme in partnership with the NGO, Mahlathini Development Foundation. Impact was examined through the conceptual lens of regulatory policy implementation and food security.

\section{Conceptual Frameworks \\ Food Security}

Forty nine percent (49\%) of KwaZulu-Natal's roughly 8,9 million people live in rural areas. There are around 609000 African households involved in agricultural production, primarily in the communal tenure areas of the province (Von Fintel \& Pienaar 2016). Although accurate data on household incomes for the rural dwellers are difficult to find, there is agreement that these are extremely low - between R1,200.00 and R2,400.00 per month. Unemployment is high and the poverty rate was estimated at around $78 \%$ as far back as 2000 (Pauw 2005). There are also numerous indications that this situation has either remained stagnant or has worsened over time (Murisa 2013).

Small-scale farmers in communal tenure areas typically rely on multiple pathways to survive (Abdu-Raheem \& Worth 2011). Survival depends most often on a combination of social grants - which pay for food and farming inputs; small-scale food production - which supplements and diversifies bought food; income support through sale of surplus produce; running of small businesses, and remittances (Aliber \& Hart 2009). Most of these smallholders farm to produce extra food $(71,5 \%)$, while a much smaller proportion $(13,8 \%)$ farm as a main source of food, or for income (5\%) (Stats SA 2020).

For most of these households, this is a balancing act of diminishing returns and very high risk, with increasing prices for food and farming inputs, low productivity, crop and livestock losses due to climate variability, lack of access to markets and lack of extension support, which has underscored the strategy by most of these households to farm for self-provisioning and extra food as their main aim (Rogan 2018). Climate resilient agriculture assists in reducing risk and improving productivity in existing small-scale farming systems (NDRC 2020). 


\section{Implementation of Regulatory Policy}

Regulatory policies and legislation seek to shape the behaviour of individuals within a specific context (Schneider \& Ingram 1990:513). They usually stipulate the provisions of what is permitted and prohibited with regard to a particular issue or condition (Anderson 1997). The Organization for Economic Cooperation and Development (OECD) argues that if governments want to improve the effectiveness of regulatory policies, they need to have an in-depth understanding of the context in which that policy is operational (OECD 2000). Understanding the context in which people live and preparing for timeous mitigation measures are key components of effective regulation (OECD 2010). They (OECD 2000) argue that an understanding of context entails an understanding of the features of the market place, the types of incentives that intended beneficiaries and organisations are likely to be motivated by to act in accordance with a regulation, and the factors that would act as a barrier to compliance.

Schneider and Ingram (1990) argue that employing capacity tools which provide information, training, education, and resources to allow individuals and groups to make decisions in line with a regulatory policy could also facilitate effective implementation of such policy.

Community members can play an important role in reducing the impacts of disasters as they are often the most vulnerable to disasters and often have important knowledge about the livelihood options available (Maskrey 2012). Studies on alternative disaster mitigation methodology, where NGOs are intervening at a local level, show that local people know their own needs and it is only they who can define the priorities for mitigation within a given context (ibid). Inclusion of interest groups in the drafting and implementation of regulatory measures is a key component to effective implementation of such measures. Rodrigo and Andrés Amo (OECD n.d. 2020) argue that their inclusion could facilitate compliance, consensus and commitment amongst interest groups. The OECD (2020) proposes that where extensive consultation with all potentially affected groups is not possible on urgent measures, policy makers should rely on advisory groups of experts from relevant areas. More specifically, they suggest that if time permits then important decisions should be subject to consultation through snap meetings with representatives of tripartite, local governments or major NGOs (ibid).

The Disaster Management Act, 2002: Amendment of Regulations issued in terms of Section 27(2) is a regulatory legislation which is intended to 
contain the spread of the COVID-19 virus by restricting the movement of people and goods. We argue that in the implementation of regulatory legislation the context of the people whose behaviour it seeks to regulate should be taken into consideration. Further, information, training, education, and resources should be provided to the affected people so that they can act within and cope with the regulations. Consultation with community members and the inclusion of interest groups in the design and implementation of regulatory policies can provide knowledge about their needs and appropriate measures that can mitigate against the negative impact of disaster management legislation.

\section{Methodology}

\section{Case Study}

The Mahlathini Development Foundation (MDF) works in poor rural communities, mainly in the southern, central and Drakensberg regions of KZN, providing agriculture and livelihoods support to around 450 small-scale farmers in communal tenure areas, across 38 villages. The support takes the form of several programmes, one of which is the Climate Resilient Agriculture programme (CRA) (MDF 2020).

Presently the CRA programme is collaboratively implemented in these villages through two programmatic thrusts:

- A Conservation Agriculture (CA) innovation programme, funded by the Maize Trust, focussing on awareness raising and implementation of a CA system appropriate to the small-scale farming system which includes field cropping using minimum tillage, soil cover and crop diversification as well as livestock integration through fodder production and supplementation (Kruger et al. 2019) and

- A community-based Climate Change Adaptation (CCA) programme, funded by the Water Research Commission focusing on a decision support process for implementation of a basket of CRA practices in soil and water conservation and intensive homestead food production (Kruger et al. 2020).

Through the CRA programme, small-scale farmers are organised into learning groups which provide the organisational setting for information sharing, 
knowledge co-creation and building of social agency; focusing also on building of local value chains and small business development. Village-based savings and loan associations (SLVAs) are central to this process. Farmers are expected to be self-motivated in terms of provision of their own labour and inputs, while MDF provides learning and mentoring support, as well as material support for experimentation with new ideas and practices (Kruger et al. 2020).

\section{Data Collection Methods}

In order to explore the impact of the COVID-19 national disaster emergency response (an eight-week hard lockdown in South Africa) on the livelihoods and resilience of small-scale farmers in the CRA programmes, interviews were conducted with a case study of small-scale farmers.

Twenty-eight small-scale farmers participated in the study, which sought to explore the social and economic impact of the lockdown on smallscale farmers. The farmers were interviewed either telephonically or face to face by MDF field staff in the following villages: Midlands (Gobizembe, Ozwathini,), Estcourt (Ntabamhlophe), Bergville (Ezibomvini, Eqeleni, Stulwane, Ndunwana). Purposive sampling was used to select participants. The sample comprised $20 \%$ of the total number of the 147 MDF beneficiaries in the selected villages. Respondents were chosen because they were members of the MDF-supported learning groups, were engaged in farming and local income generating activities, and, had agreed to be interviewed and share their experiences of the COVID-19 lockdown.

A structured interview guide was used in the interviews, which were conducted between mid-April and mid-May 2020.

\section{Data Analysis}

Four broad themes were explored in the structured interview guide:

1. Sense of resilience: stress levels, activities undertaken to provide relief, support required, and support provided to and within communities.

2. COVID-19 social distancing and physical isolation: information and knowledge, access to information about COVID-19, concerns and impacts related to social distancing and physical isolation. 
3. Livelihoods and the impact of COVID-19 lockdown on employment, finances, access to services and food security.

4. Agricultural production: food availability and access through local production, marketing and potential for continuation in the short term.

The responses to the open-ended and closed questions are presented in the findings section in this report in the form of tables and direct quotes from comments made by respondents.

Of the 28 respondents interviewed, 25 were women ranging between the ages of 44 and 70 . All respondents were unemployed and relied primarily on a range of social grants (child, orphan and disability grants and pensions) for their incomes as well as remittances from family members, small informal businesses and farming. It is clear from the interviews that the women between the ages of 42 and 49 were much more vulnerable than their older counterparts (between 62 and 68 years old). Of these younger women, $40 \%$ did not receive any social grant, while the remaining $60 \%$ received on average between 1 and 3 child grants. They were much more reliant on their own farming efforts to provide income for themselves. They were also local vendors and working in the national Community Work Programme (CWP) - both of which sources of income were inaccessible during the lockdown period.

\section{Findings}

\section{Sense of Resilience}

\section{(i) Stress levels}

Respondents rated their levels of stress in terms of fear, uncertainty and pressure on their livelihoods on a scale of 1 to 10 , where 1 is no stress at all and 10 is very stressed. The table below shows their responses.

\section{Table 1: Rating of stress level by respondents}

\begin{tabular}{|c|c|c|c|c|c|c|c|c|c|c|}
\hline & \multicolumn{1}{|c|}{ Rating of experience of stress on a scale of 1 to 10} \\
\hline Scale & 1 & 2 & 3 & 4 & 5 & 6 & 7 & 8 & 9 & 10 \\
\hline & 2 & & & 1 & & & & 4 & 8 & 13 \\
\hline
\end{tabular}

Only three respondents experienced low stress levels, while the other 25 att- 
ested to high stress levels and of these, 13 experienced extreme stress. In the follow-up question relating to the cause of their stress, respondents stated that this related mostly to their fear of being infected, of being unable to provide food for their families and being unable to cope financially in the coming months.

\section{(ii) Activities during lockdown}

When asked about the activities they had undertaken during lockdown to provide relief for themselves, respondents reported that they had engaged in: field cropping (15) - mainly harvesting, sale and storage of maize, beans, cowpeas, pumpkins, sweet potatoes and potatoes; vegetable production (6); livestock management (7); homestead maintenance and cleaning (8); local food supply through farmer centres and vending (2) and sewing clothes and masks (2).

Their responses indicated that small-scale farmers in the MDF CRA programme generally continued with their agricultural production activities as best they could during lockdown. However, a few farmers reported difficulties accessing their fields and livestock due to police enforcement of curfews and restriction of movement in the villages.

\section{(iii) Support required under lockdown}

Respondents were asked an open-ended question in relation to the support they required during these times. The table below summarises the main support that they required and the number of respondents who mentioned each specific support activity.

Table 2: Support required by small-scale farmers during the COVID-19 extended lockdown

\begin{tabular}{|l|c|}
\hline Support Requested & $\begin{array}{c}\text { No. of } \\
\text { respondents }\end{array}$ \\
\hline Seedlings for winter vegetable production & 24 \\
\hline $\begin{array}{l}\text { Support for vegetable production: fencing, water, seed, } \\
\text { seedlings, pesticides, advice }\end{array}$ & 12 \\
\hline Food parcels & 8 \\
\hline $\begin{array}{l}\text { Support for livestock production: winter cover crops and } \\
\text { fodder supplementation }\end{array}$ & 5 \\
\hline
\end{tabular}




\begin{tabular}{|l|c|}
\hline $\begin{array}{l}\text { Assistance with transport to town: for grants, groceries, } \\
\text { farming inputs }\end{array}$ & 4 \\
\hline Assistance with education of children & 3 \\
\hline More storage drums for maize harvests & 1 \\
\hline Support for broiler production & 1 \\
\hline Sanitisers and masks & 1 \\
\hline Cloth and materials for making masks & \\
\hline
\end{tabular}

The vast majority of respondents (24) requested assistance with winter vegetable production, especially assistance with procurement of seedlings since they had been unable to access seedlings during lockdown. These respondents mentioned that the demand for fresh produce in the villages had risen sharply since the beginning of lockdown, as had household food requirements. Around half (12) of them were also not well set up for gardening, as they mostly lacked access to water (for both household purposes and irrigation) and fencing. A further five respondents requested support for livestock and broiler production. One respondent requested more storage drums for her maize harvest, stating that she intended to keep her whole harvest this year, rather than selling the maize which she would normally have done. Only a relatively small number of households (8) requested food parcels, with most of these requests coming from Ntabamhlophe and Gobizembe villages.

There were concerns from some respondents (4) around access to transport, which was severely limited due to lockdown regulations on the use and provision of public transport. Almost all respondents were concerned about the closure of schools and their children not being educated and they were worried about the implications of this. However, only three respondents specifically asked for support for educating their children during the school closure period.

The results of the study showed that in terms of small-scale farmers' sense of resilience, they experienced high levels of stress during the lockdown period. However, many continued with their agricultural production activities, even though they struggled to access their fields, farming inputs and livestock, due to police enforcement of curfews and restriction of movement. Most indicated that they required assistance with winter vegetable production, for example, access to seedlings. For about half of the farmers, access to water for household and farming was a problem. 


\section{COVID-19 Social Distancing and Physical Isolation}

\section{(i) Information and knowledge of COVID-19}

Respondents were asked a series of questions related to their understanding of COVID-19. They were asked to rate their levels of agreement with the statements.

\section{Table 3: Access to information related to COVID-19}

\begin{tabular}{|l|c|c|c|c|c|}
\hline $\begin{array}{l}\text { COVID-19 } \\
\text { information }\end{array}$ & $\begin{array}{c}\text { Strongly } \\
\text { Disagree }\end{array}$ & Disagree & Neutral & Agree & $\begin{array}{c}\text { Strongly } \\
\text { Agree }\end{array}$ \\
\hline $\begin{array}{l}\text { I am not worried } \\
\text { about being infected }\end{array}$ & 15 & 3 & 1 & 2 & 1 \\
\hline $\begin{array}{l}\text { I am confident that } \\
\text { my family members } \\
\text { and I would recover } \\
\text { if we were to be } \\
\text { infected }\end{array}$ & 5 & 6 & 7 & 3 & 1 \\
\hline $\begin{array}{l}\text { I have access to } \\
\text { accurate facts and } \\
\text { information on } \\
\text { when to get tested }\end{array}$ & 6 & 8 & 8 & 8 & \\
\hline $\begin{array}{l}\text { I have access to } \\
\text { accurate facts and } \\
\text { information on } \\
\text { when to self- } \\
\text { quarantine }\end{array}$ & 4 & 10 & & & \\
\hline
\end{tabular}

Most of the small-scale farmers were very worried about being infected. However, an equal number were confident and not so confident about whether they would recover once infected. Participants were somewhat ambivalent about having access to accurate facts and information on when to get tested. Most shared one respondent's feeling that '( $\mathrm{t})$ he officials are trying to punish $u s$ '. This ambivalent attitude was also evident in their responses to having accurate information on self-quarantine. The follow-up discussion to this statement revealed that respondents did have information about requirements for self-quarantine, but felt that they would not be able to fulfil those require- 
ments, given their crowded living conditions in small houses.

All respondents reported being aware of COVID-19 and that they had received information regarding sanitisation, social distancing, wearing of masks and COVID-19 testing primarily from the radio and TV. A respondent commented that they had ' $(n)$ o access to real facts, just what we see on TV and hear on radio and from our neighbours'. A few respondents (3) reported that they had been visited by community health workers, had been tested and given an emergency number to call. One also said, '( $s$ )omeone has come to conduct a survey; not sure who it was'. Some farmers reported that community health workers had done the rounds and discussed issues with community members (in 2 out of the 8 villages). Despite this, respondents were still confused about how COVID-19 spread and found the prospect of anyone in their household becoming ill very alarming. They also stated that they would be unable to adhere to the physical isolation protocols and feared being tested due to the many stories and rumours that had circulated about being quarantined. As a result, people were not volunteering to be tested and a few even said that they would hide if compulsory testing were to be carried out in their village.

Respondents also reported that they were aware of where to get help if someone became ill, but argued that the clinics and local hospitals were already very busy. They said that it was difficult for them to get their monthly medication and check-ups and people raised concerns about spending many hours in long queues, with the consequent risk of infection.

\section{(ii) Community responses to COVID-19 (social distancing and physical isolation)}

Farmers were asked about social distancing and community level experiences of the lockdown.

\section{Table 4: Community-level responses to COVID-19 and the lockdown}

\begin{tabular}{|l|c|c|c|c|c|}
\hline $\begin{array}{l}\text { COVID-19 } \\
\text { community } \\
\text { response }\end{array}$ & $\begin{array}{l}\text { Strongly } \\
\text { Disagree }\end{array}$ & Disagree & Neutral & Agree & $\begin{array}{l}\text { Strongly } \\
\text { Agree }\end{array}$ \\
\hline $\begin{array}{l}\text { My community has } \\
\text { banded together } \\
\text { during this time }\end{array}$ & 1 & 13 & 7 & 1 & \\
\hline
\end{tabular}


Desiree P. Manicom \& Erna Kruger

\begin{tabular}{|l|l|l|l|l|l|}
\hline $\begin{array}{l}\text { I want to continue } \\
\text { supporting my local } \\
\text { businesses }\end{array}$ & S & 13 & 3 & 1 & 1 \\
\hline $\begin{array}{l}\text { Social distancing } \\
\text { has not had a } \\
\text { negative impact on } \\
\text { my community }\end{array}$ & 2 & 11 & 8 & 7 & \\
\hline $\begin{array}{l}\text { Vulnerable } \\
\text { members of my } \\
\text { community are } \\
\text { well-supported } \\
\text { during this time }\end{array}$ & 17 & 3 & & 2 & \\
\hline $\begin{array}{l}\text { I feel safe when I go } \\
\text { outside/to the shops } \\
\text { during this time }\end{array}$ & & & & & \\
\hline
\end{tabular}

Most farmers felt that the community had not banded together during this time of crisis (13) and seven felt neutral about community solidarity. In Bergville, a respondent said ' $(w)$ e have continued to be there for each other as usual but there is increased pressure on food availability'.

Eighteen respondents said that they wanted to continue supporting their local businesses. These respondents said, '( $w$ ) e are supporting local spaza shops, because it is very difficult to go to town - but they are more expensive'. However, one respondent said, '(l)ocal shops do not follow safety precautions; local businesses have slowed down; initially they were closed, and some have not re-opened'.

Thirteen respondents felt that social distancing had had a negative impact on their community, with five feeling strongly about this statement.

Eleven respondents also felt that vulnerable members of their community were not well supported during this time while eight felt neutral about the statement. A respondent from Ozwathini commented, '(w)e wish to visit old people to help them, but we are scared because we haven't been tested for the virus' and in Ntabamhlophe the following comment was made: 'Vulnerable community members are not supported by anyone. Even the government officials have not helped'. Another respondent said, '(i)n some villages the municipality took people's names for food parcels, but never returned to deliver them'. However, there were seven respondents who felt that 
vulnerable people were well supported. These respondents were from Gobizembe and Bergville. In Gobizembe, one elderly woman said, '( $t$ )he $\mathrm{DoH}$ has come to deliver pills for those people with chronic conditions and have given them enough supply for a few months. We are so grateful'.

Most respondents (20) did not feel safe about going outside and to shops during this time. Fear of being infected was a reason for respondents not feeling safe about going to town. They reported, '( w)e do not feel safe going to town as there are many people and there is a risk of being infected'. Further, '(w)e do not feel safe going to town as we aren't sure whether we will get the disease or not', and '(w) e can't go to shops due to the lack of transport and because we are scared of getting infected'.

An open-ended question was asked in relation to farmers' top three concerns regarding social distancing. The table below categorises and summarises their top three concerns.

Table 5: Top concerns related to the impacts of social distancing and physical isolation under emergency COVID-19 lockdown procedures

\begin{tabular}{|l|c|}
\hline $\begin{array}{l}\text { Concerns related to social distancing and physical } \\
\text { isolation }\end{array}$ & $\begin{array}{c}\text { No. of } \\
\text { respondents } \\
\text { (N=22) }\end{array}$ \\
\hline Transport: difficult to get transport to town & 11 \\
\hline $\begin{array}{l}\text { Education: children can't go to school and no provision is } \\
\text { made for them }\end{array}$ & 11 \\
\hline Farming: access to farming fields, inputs, marketing & 6 \\
\hline Poverty: not enough food for the household & 6 \\
\hline Harvested food will run out soon & 5 \\
\hline Food: scarcity in shops and locally, long queues & 4 \\
\hline Social grants: not sufficient for need & 4 \\
\hline Social grants: difficulties in getting grants & 3 \\
\hline The economy is being destroyed & 3 \\
\hline Water scarcity & 2 \\
\hline Staying at home and doing nothing; leads to depression & 2 \\
\hline Not being able to see our children & 2 \\
\hline No being able to attend church & 1 \\
\hline Unable to visit banks to make payments such as loans & 3 \\
\hline There is no fool proof way to protect yourself & \\
\hline
\end{tabular}




\begin{tabular}{|l|l|}
\hline Harvests being stolen in the fields & 1 \\
\hline Cannot attend community meetings & 1 \\
\hline
\end{tabular}

The most pressing concerns mentioned by the most participants (11) were the lack of transport to get to town and children being unable to go to school, with no provision being made for them. School closures were also a major concern, both due to the lack of education and the loss of meals for school-going children. The lockdown's social distancing regulations affected farming by restricting access to fields and grazing areas, preventing farmers from acquiring inputs and resulted in the loss of marketing outlets (6). Not having enough food for household members was also mentioned as a pressing concern for six households - all these households were located in Ntabamhlophe. Farmers also felt that social grants were too meagre to support their households. Social distancing regulations which prevented them from attending church and community meetings and visiting their children were a minor concern.

Nearly all small-scale farmers were worried about becoming infected with COVID-19 and subsequently about being infected by going into town. However, they were confused about the actual transmission of the virus. Farmers expressed fears about getting tested because of rumours about being quarantined. They felt they would not be able to self-quarantine due to their crowded living conditions. Respondents stated that strict enforcement of social distancing protocols by the police and armed forces had negatively affected a sense of community in the villages - they could not band together or work together during this time. They continued to support local businesses but they experienced difficulties with travelling to town because of the lockdown restrictions on public transport and restrictions on movement. Lockdown social distancing restrictions impacted negatively on their ability to visit and support vulnerable members of their community and they felt that the government had not assisted them enough. Their most pressing concerns during the lockdown were the restriction of transport into town and their children not being able to go to school, resulting in the loss of both meals and education.

\section{Livelihoods and the Impact of COVID-19 Lockdown}

In the rural communal tenure villages, livelihoods (income, food security and farming) are all strongly interlinked. Respondents were posed a series of 
statements related to the impact of COVID-19 lockdown regulations on their livelihoods (incomes and expenditure), their access to food and their farming activities.

\section{(i) Impact on livelihoods}

The table below summarises respondents' levels of agreement or disagreement with statements related to the impact of COVID-19 lockdown on their livelihoods.

\section{Table 6: Impact of COVID-19 and lockdown on livelihoods}

\begin{tabular}{|l|c|c|c|c|c|}
\hline Livelihoods impacts & $\begin{array}{c}\text { Strongly } \\
\text { Disagree }\end{array}$ & Disagree & Neutral & Agree & $\begin{array}{c}\text { Strongly } \\
\text { Agree }\end{array}$ \\
\hline $\begin{array}{l}\text { My job/work/informal } \\
\text { trading/farming is not at } \\
\text { risk }\end{array}$ & 17 & 2 & 1 & 2 & \\
\hline $\begin{array}{l}\text { My spending habits } \\
\text { have not changed }\end{array}$ & 9 & 8 & 4 & 1 & \\
\hline $\begin{array}{l}\text { I am confident that I } \\
\text { can continue providing } \\
\text { for my family }\end{array}$ & 6 & 9 & 1 & 6 & \\
\hline $\begin{array}{l}\text { I am not worried about } \\
\text { the impact of COVID- } \\
19 \text { on the economy }\end{array}$ & 16 & 3 & 2 & & 1 \\
\hline
\end{tabular}

Most respondents (19) felt that their employment, informal trading and farming activities were at risk due to the lockdown protocols. Respondents explained this risk in terms of impact on their farming activities: 'We depend on farming for income and don't have enough money to buy food'. The lack of money was a consequence of lockdown restrictions on movement: 'We cannot sell our crops, the only demand that seems to be high is for vegetables'. While others said, '(w)e cannot sell our maize and bean harvest as we usually do, so we have been eating most of our crops' and '(d)emand for maize has decreased as the vendors in town have been closed'. The lockdown restrictions on businesses operating also impacted on their farming activities: 'Some businesses have closed, so access to supplies is difficult'.

Seventeen respondents reported that they had changed their spending 
patterns to adjust to increased household demands during this time. They reported, 'I am now spending more money on food as more people are at home and I also have to travel to town twice to get the monthly supplies because of the restrictions. Prices have increased' and '( $w)$ e cannot afford the higher prices as we are reliant on social grants'.

These feelings were reflected in respondents (15) stating that they did not feel confident that they could continue providing for their families if these conditions continued: 'It is worrying because we do not know how long this will last; if it lasts for a long time we will fail to look after ourselves; we are already struggling in terms of food'. Due to farmers being unable to go to their fields and sell their produce and buy inputs the farmers stated, '(w)ithout farming we will not have enough food to provide for our family' and ' $(t)$ here is not enough food to feed my family'.

Many respondents (19) were also worried about the effect of COVID19 on the economy. One farmer said, '( $t$ )he economy is going down and poverty is increasing'.

\section{(ii) Access to food}

Further questions were asked in relation to farmers' access to food. Respondents reported on access to both food bought from shops and food produced by the households through farming activities.

Table 7: COVID-19 and lockdown impact on access to food

\begin{tabular}{|l|c|c|c|c|c|}
\hline Access to food & $\begin{array}{c}\text { Strongly } \\
\text { Disagree }\end{array}$ & Disagree & Neutral & Agree & $\begin{array}{c}\text { Strongly } \\
\text { Agree }\end{array}$ \\
\hline $\begin{array}{l}\text { I am confident } \\
\text { that I can } \\
\text { continue to } \\
\text { afford food and } \\
\text { supplies }\end{array}$ & 10 & 3 & 1 & 8 & \\
\hline $\begin{array}{l}\text { I am confident } \\
\text { that my } \\
\text { household can } \\
\text { continue to } \\
\text { access basic } \\
\text { utilities and }\end{array}$ & 9 & 5 & 3 & 3 & \\
\hline
\end{tabular}




\begin{tabular}{|l|l|l|l|l|l|}
\hline $\begin{array}{l}\text { services (e.g. } \\
\text { internet, } \\
\text { electricity, } \\
\text { transport, water) }\end{array}$ & & & & & \\
\hline $\begin{array}{l}\text { I do not see the } \\
\text { need to stock up } \\
\text { on bulk-buy } \\
\text { supplies }\end{array}$ & 6 & 5 & 6 & 5 & \\
\hline $\begin{array}{l}\text { I am confident } \\
\text { that my } \\
\text { household will } \\
\text { not run out of } \\
\text { food and } \\
\text { supplies }\end{array}$ & 7 & 7 & 1 & 7 & \\
\hline
\end{tabular}

Most respondents were not confident that they could continue to afford food and supplies: 'We have no source of income except for farming, we cannot access grants'; 'I am supported by my children, who are currently at home, so there is insecurity as to whether our quality of life will go down'.

Respondents also felt insecure about continuing to access basic utilities and services. However, some farmers in Ntabamhlophe (3) said, '(i)n Ntabamhlophe we have support through Lindelwa from Lima Rural Development Foundation and MDF in terms of transport and farming activities'.

Very few respondents felt confident that their households would not run out of food and supplies: 'I am not confident that we won't run out of food, since we don't have money and can 't provide for our family'; ' $(w)$ e are in fear of being unable to support our family; the only option is to sell livestock, but those were for lobola and we should not sell them'; and '( $w)$ e do not have enough food for the family and are struggling'.

Bulk buying was seen as a good coping mechanism during lockdown, but at least half the respondents felt that they could not afford it: 'We see a need for bulk buying during this time, so that we will have enough food, but cannot do so as we rely on the pensions for an income and there is not enough'.

Most farmers felt their livelihoods were at risk due to restrictions on their movement to sell their produce and to access supplies for farming. They were incurring additional costs for food due to having more household 
members, more trips into town to buy food and higher food prices in shops during lockdown. Food security and shortages were a real concern as their farming activities (going to fields, selling produce and buying inputs) were restricted during lockdown. Many were worried about the effects of COVID19 on the economy. Farmers did not feel confident about their access to food since farming was one of their main income and food sources, and accessing social grants was difficult during the lockdown.

\section{Agricultural Activities}

(i) Production impacts

The impact of COVID-19 lockdown regulations on the agricultural production of small-scale farmers was explored in terms of their ability to provide food for their households through their agricultural production.

Table 8: COVID-19 lockdown impact on agricultural production

\begin{tabular}{|l|c|c|c|c|c|}
\hline $\begin{array}{l}\text { Production } \\
\text { impacts }\end{array}$ & $\begin{array}{l}\text { Strongly } \\
\text { Disagree }\end{array}$ & Disagree & Neutral & Agree & $\begin{array}{c}\text { Strongly } \\
\text { Agree }\end{array}$ \\
\hline $\begin{array}{l}\text { I am confident I } \\
\text { can continue } \\
\text { with my } \\
\text { agricultural } \\
\text { production } \\
\text { activities }\end{array}$ & 1 & 2 & 3 & 14 & 2 \\
\hline $\begin{array}{l}\text { I am confident } \\
\text { that as a family } \\
\text { we can produce } \\
\text { enough food for } \\
\text { our household }\end{array}$ & 1 & 6 & 6 & 8 & 1 \\
\hline $\begin{array}{l}\text { I am confident } \\
\text { that I can access } \\
\text { the inputs and } \\
\text { supplies I need to } \\
\text { continue farming } \\
\text { activities }\end{array}$ & 1 & 11 & 4 & 4 & \\
\hline $\begin{array}{l}\text { I have enough } \\
\text { support to }\end{array}$ & & 5 & 8 & 6 & 1 \\
\hline
\end{tabular}




\begin{tabular}{|l|l|l|l|l|l|}
\hline $\begin{array}{l}\text { continue and } \\
\text { intensify my } \\
\text { productive } \\
\text { activities }\end{array}$ & & & & & \\
\hline
\end{tabular}

A surprisingly high number of respondents (16) felt confident that they could continue with their agricultural production activities: 'I am confident that if I get some support, I can continue with farming' and at least a third felt confident that they could produce enough food for their households. However, only seven felt that they had enough support to continue and intensify their productive activities. This was mostly related to the respondents' (12) difficulties in accessing inputs and supplies to continue with their farming: ' $I$ cannot continue farming without support, as the inputs, such as seedlings are now not available'. However, there was some optimism: 'If we can get seedlings, we can continue with our farming; the only support we get is from MDF'.

Respondents further mentioned that their ability to access farming inputs such as seed, seedlings, manure, compost, poultry feed, poultry supply inclusion, day old chicks, agrochemicals, packaging, and tools had been severely hampered due to lack of transport, shop closures, limited cash flow. They also mentioned that their usual support from government and institutional extension staff was not available during this period. Some respondents spoke of lockdown regulations preventing them from accessing farming inputs: 'It has been difficult to go and buy requirements such as seedlings as police would not permit us'. They confirmed that it was only staff from a few NGOs such as MDF and Lima who were still supporting them during the lockdown.

\section{(ii) Marketing agricultural produce}

Respondents also mentioned that marketing their produce had been severely disrupted. In some communities (Gobizember \& Ozwathini), which are close to large urban centres, 'bakkie' trading had been an important outlet; mainly for field crops such as green mealies, amadumbe and sweet potatoes. As these are informal trading processes this kind of trading was allowed during lockdown. However, informal traders had struggled to get licences to operate during this period and were harassed at police checkpoints. Farmers therefore resorted to consuming as much of their own harvests as possible - harvests which they would normally have sold locally. They also reported that they experienced substantial losses. 
According to the respondents, they were not able to satisfy the demand for fresh produce in the short term as they are used to a much smaller local market. The respondents did, however, report that they were eager to increase their production quickly to take advantage of this opportunity (MDF, Field Reports, April-May 2020).

Some respondents also requested advice and mentoring from MDF as most had started focussing on winter vegetable production, small livestock (with a focus on layers and rabbits) and fodder supplementation for livestock. In several villages the programme participants had all bought extra storage drums to accommodate their full harvests for home consumption, since they anticipated a continued slow local market for field crops. Requests for assistance with agricultural water supply were numerous.

\section{(iii) Agricultural capacity and production}

Respondents also outlined the size and production capacity of their present farming enterprises.

In the Midlands and Estcourt, garden sizes are, on average, between $50 \mathrm{~m}^{2}$ and $100 \mathrm{~m}^{2}$ and fields are between $400 \mathrm{~m}^{2}$ and $2000 \mathrm{~m}^{2}$. Most of these respondents had gardens and all had fields. Only a few owned large livestock like cattle and pigs. In Bergville, the situation is slightly different with garden sizes, on average, between $50 \mathrm{~m}^{2}$ and $200 \mathrm{~m}^{2}$ and fields generally between 2 $000 \mathrm{~m}^{2}$ and $8000 \mathrm{~m}^{2}$. Here more respondents $(30 \%)$ owned large livestock, with an average of ten cattle per household.

The table below summarises crops grown and months of food provisioning per household, as outlined by the survey respondents.

Table 9: Months of food provisioning for households from farming activities, during and after the COIVD-19 hard lockdown

\begin{tabular}{|l|l|l|l|l|}
\hline Produce & \multicolumn{2}{|l|}{ Field crops } & Vegetables \\
\hline Area & Maize & Beans & $\begin{array}{l}\text { Sweet } \\
\text { potatoes, } \\
\text { potatoes, } \\
\text { pumpkins }\end{array}$ & $\begin{array}{l}\text { Cabbage, } \\
\text { spinach, green } \\
\text { pepper, chil- } \\
\text { lies, onions, } \\
\text { beetroot }\end{array}$ \\
\hline Bergville & $\begin{array}{l}\text { Average } 6 \\
\text { months (2-9 }\end{array}$ & $\begin{array}{l}2 \text { months; } \\
10-50 \mathrm{~kg}\end{array}$ & 3 months & $\begin{array}{l}\text { Small } \\
\text { quantities to }\end{array}$ \\
\hline
\end{tabular}


Impact of Disaster Management Regulations on Small-scale Farmers

\begin{tabular}{|l|l|l|l|l|}
\hline & $\begin{array}{l}\text { months; 100- } \\
\text { 800kg) }\end{array}$ & $\begin{array}{l}\text { supplement } \\
\text { bought food }\end{array}$ \\
\hline Midlands & $\begin{array}{l}\text { Average 2 } \\
\text { months (1-3 } \\
\text { months) }\end{array}$ & $\begin{array}{l}\text { Average 2 } \\
\text { months (1-3 } \\
\text { months) }\end{array}$ & $\begin{array}{l}\text { Average 2 } \\
\text { months (1-3 } \\
\text { months) }\end{array}$ & $\begin{array}{l}\text { Small } \\
\text { quantities to } \\
\text { supplement } \\
\text { bought food }\end{array}$ \\
\hline Estcourt & $\begin{array}{l}\text { Average 1,5 } \\
\text { months (1-3 } \\
\text { months) }\end{array}$ & $\begin{array}{l}\text { Average 1,5 } \\
\text { months (1-3 } \\
\text { months) }\end{array}$ & $\begin{array}{l}\text { Average 1,5 } \\
\text { months (1-3 } \\
\text { months) }\end{array}$ & $\begin{array}{l}\text { Small } \\
\text { quantities to } \\
\text { supplement } \\
\text { bought food }\end{array}$ \\
\hline
\end{tabular}

The Bergville respondents focussed more on field cropping and had a sufficient supply of staples - mainly maize and beans - to see them through a minimum of six months, on average. The Midlands participants had enough food for an average of two months, and Estcourt for one to one and a half months. This low production was also reflected in their requests for food parcels, which were the highest in Estcourt and the lowest in the Bergville villages, where respondents did not focus on food parcels, but requested assistance with agricultural inputs. What has emerged from the research, is that the MDF CRA programme participants in Bergville and the Midlands are more food secure and resilient than their counterparts in Estcourt who had not had the benefit of an extended period of involvement in the MDF facilitated CRA programmes.

A high number of respondents felt confident that they could continue with their agricultural production but only if they received support (access to inputs) for their farming. The lockdown restrictions on movement of persons and sale of certain goods had severely affected their ability to access farming inputs. Their usual support from government extension staff was absent during lockdown, however a few NGOs like MDF and Lima were present. Marketing of agricultural produce was severely disrupted due to lockdown restrictions on movement and restrictions on informal trading. The lockdown restrictions had brought about an increased demand for their produce in their villages and although they were eager to meet this demand, they were restricted from producing and increasing their production to satisfy this need. Despite the restrictions on their production MDF CRA programme participants in Bergville and Midlands were more food secure and resilient, while villages in Estcourt were less so and more reliant on food parcels as they had not been involved for as long in the MDF CRA programmes. 


\section{Discussion}

The findings of this case study point to some of the most common limitations that occur when drawing up and implementing disaster regulations in general. In this case, it points to the limitations of the lockdown regulations which were included as amendments to The Disaster Management Act, 2002 and designed to flatten the curve of the spread of COVID-19.

Interest groups (C19 National Food Group) representing the interests of small-scale farmers were not consulted during the drafting of the lockdown regulations; however, they took the initiative and attempted to engage government through submissions on the limits of the lockdown regulations and mitigation strategies. However, they were not included in the initial drafting or implementation and could only make their submissions once the lockdown measures were already being implemented. They presented a contextual analysis of the social and economic context of small-scale farmers and proposed alternative mitigating measures for these farmers.

Regulation measures affect all citizens in society but their impacts are experienced differently because of the systemic inequalities in South Africa. Consultation with the public would minimise costs and impacts and improve regulation.

The failure to understand the context in which small-scale farmers live and the lack of consultation with small-scale farmers and their interest groups in drafting and implementing COVID-19 lockdown measures during hard lockdown, is evidenced in this study by the negative impacts that the regulatory measures had on these farmers' sense of resilience, sense of community, their livelihoods and agricultural activities. It points to the limits of the South African government's initial 'command and control' mechanisms to implement hard lockdown. Some of the consequences of employing a nonconsultative, top-down approach to drafting and implementing regulatory measures are discussed by looking at how the specific regulations impacted on small-scale farmers lives, below.

\section{Conclusion}

The COVID-19 lockdown regulations presented many challenges to smallscale farmers' food security, livelihoods and agricultural activities. Specifically, this related to loss of access to local markets and supplies of 
agricultural inputs. The challenges experienced relate to the promulgation of the amendments to the regulations of The Disaster Management Act, 2002 which did not sufficiently take into account the social and economic context in which small-scale farmers live and their vulnerability. This continued to reflect how the government's post-apartheid policies and programmes favour a food economy that is dominated by corporate agricultural producers, to the disadvantage of small-scale agricultural producers and suppliers. The implementtation of the regulations failed to acknowledge the importance of small-scale farmers' role in the provision of food in their local communities and in ensuring their own food security.

In a submission to government during the hard lockdown the $\mathrm{C} 19$ National Food Group (2020) argued that support for small-scale farmers was crucial during lockdown - for their survival as local food suppliers and as farmers. They proposed that the longer-term impacts of COVID-19 would require a changed form of economic organisation, one that emphasises and supports 'more localised food economies that are responsive to local food needs, short supply chains to reduce travel, and local open air markets that can flexibly accommodate embedded social distancing measures'.

They also argued that:

(t)he provision of fresh produce to vulnerable communities is critical both from a nutritional diversity and health perspective, but also to sustain household and smallholder producer livelihoods through this crisis and in the period of economic reconstruction beyond. Smallholder producers can play a critical role in the necessary restructuring of food systems that will follow this immediate crisis (C19 National Food Group 2020).

The results of this study found that the small-scale farmers in this study who are part of the climate resilient agriculture learning groups supported by MDF, were optimistic about their ability to produce enough food for themselves and for sale of surplus in their communities as a self-reliance strategy that will protect their livelihoods. 


\section{References}

Aliber, M. \& T. Hart 2009. 2009. Should Subsistence Agriculture be Supported as a Strategy to Address Rural Food Insecurity? Agrekon 48,4: 434 - 458. https://doi.org/10.1080/03031853.2009.9523835

Anderson, J. 1997. Public Policy-making: An Introduction. $3^{\text {rd }}$ Edition. New York: Houghton Mifflin Company.

C19 National Food Group 2020. Submission to Amend the COVID-19 Agricultural Disaster Relief Procedures and Criteria for Small Farmers.

Cf. for instance, https://alicenews.ces.uc.pt/index.php?lang=1\&id=30686

Disaster Management Act 2002. Amendment of Regulations issued in terms of section 27(2). 2020. SI 2020/465. Pretoria: Government Gazette

Abdu-Raheem, I., K. Worth \& S. Worth 2011. Household Food Security in South Africa: Evaluating Extension's Paradigms Relative to the Current

Food Security and Development Goals. South African Journal of Agricultural Extension 39,2: 91 - 103.

Kruger, E., P. Ngcobo, M. Dlamini \& T. Mathebula 2017. Desktop Review of Climate Smart Agriculture and Soil and Water Conservation. Project No K5/2719/4. Pretoria, South Africa: The Water Research Commission.

Available at: https://www.mahlathini.org/our-work/water-researchcommission-knowledge-creation-for-water-and-soil-

practices/deliverable-1-desktop-review-of-climate-smart-agricultureand-soil-and-water-con/

Kruger, E., P. Ngcobo, M. Dlamini \& T. Mathebula 2020. Final Report: Results of Pilots. Collaborative Knowledge Creation and Mediation Strategies for the Dissemination of Soil and Water Conservation Practices and Climate Smart Agriculture Practices in Smallholder Farming Systems. Pretoria: The Water Research Commission (K5/2719/4).

Kruger, E., H. Smith, M. Mathebula \& M. Dlamini 2019. Annual Progress Report for the CA - Smallholder Farmer Innovation Programme in the Midlands. Pretoria: The Maize Trust.

Kruger, E., H. Smith, P. Ngcobo, M. Dlamini \& T. Mathebula 2020. (In Press).

CA Innovation Systems Build Climate Resilience for Smallholder Farmers in South Africa. In A. K. et al. (ed.): Conservation Agriculture in

Africa: Climate Smart Agriculture Development. s.1.: CA International. Maskrey, A. 2012. Defining the Community's Role in Disaster Mitigation. 
Practical Action Technical Brief.

Murisa, T. 2013. Prospects for Smallholder Agriculture in Southern Africa.

Chapter 8. Hendricks, F., L. Ntsebeza \& K. Hellier (eds.): The Promise of Land: Undoing a Century of Dispossession in South Africa. Auckland Park: Jacana Press.

https://issuu.com/jacanamedia/docs/the_promise_of_land_flipping_previ $\underline{\mathrm{e}}$

NDRC 2020. Climate Change and Agriculture: Improve Climate Resilience and Soil Health. Available at: https://www.nrdc.org/issues/improveclimate-resilience-and-soil-health

Organisation for Economic Cooperation and Development 2000. Reducing the Risk of Policy Failure: Challenges for Regulatory Compliance. Paris: OECD.

OECD 2020. Tackling Coronovirus (COVID-19): Contributing to a Global Report: Regulatory Quality and COVID-19: Managing the Risks and Supporting the Recovery. http://www.oecd.org/coronavirus/policyresponses/regulatory-quality-and-covid-19-managing-the-risks-andsupporting-the-recovery-3f752e60/

(Accessed 2 July 2020)

OECD 2010., Chapter 4 The development of New Regulations in the Better Regulation in Europe. UK: OECD. http://www.oecd.org/gov/regulatorypolicy/44912147.pdf

(Accessed 2 July 2020)

OECD n.d. Background Document on Public Consultation prepared by Delia Rodrigo, Administrator, and Pedro Andrés Amo, Consultant, Regulatory Policy Division, Public Governance and Territorial Development

Directorate. https://www.oecd.org/mena/governance/36785341.pdf (Accessed 2 July 2020)

Pauw, K., C. Punt \& M. van Schoor 2005. A Profile of KZN: Demographics, Poverty, Inequality and Unemployment. Elsenberg, Western Cape: PROVIDE Project Background Papers (2005; 1,5).

Rogan, M. 2018. Food Poverty, Hunger and Household Production in Rural

Eastern Cape Households. Development Southern Africa 35,1: 90 - 104. https://doi.org/10.1080/0376835X.2017.1358602

Schneider, A. \& H. Ingram 1990. Behavioural Assumptions of Policy Tools.

The Journal of Politics 52,2: 510 - 529. https://doi.org/10.2307/2131904 Smith, H., E. Kruger, J. Knot \& J. Blignaut 2017. Conservation Agriculture 
in South Africa: Lessons from Case Studies. Conservation Agriculture for Africa: Building Resilient Farming Systems in a Changing Climate.

CAB International. https://doi.org/10.1079/9781780645681.0214.

Republic of South Africa 2020. About Alert System. Available at:

https://www.gov.za/covid-19/about/about-alert-system

(Accessed on 29 August 2020.)

Statssa 2017. The Extent of Food Security in South Africa. South Africa. The

Disaster Management Act, 2002: Amendment of Regulations issued in Terms of Section 27(2).

Stats SA 2020. General Household Survey. Pretoria: Statistical release P0318. Von Fintel, D. \& L. Pienaar 2016. Small Scale Farming and Food Security: The Enabling Role of Cash Transfers in South Africa's Former Homelands. ERSA working paper 647.

Desiree. P. Manicom Senior Lecturer Policy and Development Studies Programme School of Social Sciences University of KwaZulu-Natal.

Manicom@ukzn.ac.za

Erna Kruger Director: Mahlathini Development Foundation Pietermaritzburg KwaZulu-Natal South Africa info@mahlathini.org 